\title{
TAXONOMIC IDENTITY OF ARISAEMA CONDAOENSE (ARACEAE) BASED ON NEW MORPHOLOGICAL AND MOLECULAR DATA
}

\author{
Van Hong Thien ${ }^{1}$, Phi Nga Nguyen ${ }^{2}$, Luu Hong Truong ${ }^{3,4, 凶}$ \\ ${ }^{1}$ Institute of Biotechnology and Food Technology, Industrial University of Ho Chi Minh City \\ ${ }^{2}$ University of Science, Vietnam National University of Ho Chi Minh City \\ ${ }^{3}$ Graduate University of Science and Technology, Vietnam Academy of Science and Technology \\ ${ }^{4}$ Southern Institute of Ecology, Vietnam Academy of Science and Technology \\ ${ }^{凶}$ To whom correspondence should be addressed. E-mail: hongtruongluu@gmail.com
}

Received: 21.7.2017

Accepted: 25.10 .2017

\section{SUMMARY}

\begin{abstract}
Arisaema condaoense V.D. Nguyen was described as a new species from Con Dao National Park, Ba RiaVung Tau Province, Vietnam in 2000. However, this species has been suspected of being a form of Arisaema roxburghii Kunth, a species widespread in the whole Indochina and Malay Peninsula. This was due to the original description based on dried specimens with male inflorescences only. Morphological characteristics of female inflorescences, which are of taxonomical importance to identify the species, have not been known. In June 2015, we re-sampled the plant in Con Dao National Park with both male and female inflorescences for detailed examination of morphological characteristics. Besides, the matK gene of the chloroplast genome of this species was sequenced to analyse its phylogenetic relationship with other Arisaema species. The gathered morphological and molecular data indicate that $A$. condaoense is certainly a distinct species, not a synonym of $A$. roxburghii. The noted morphological characteristics also provide key differences to distinguish $A$. condaoense from two other morphologically close species of sect. Fimbriata (i.e A. maxwellii from Thailand and $A$. pierreanum from Vietnam which also share yellow spathes and several other characteristics in common), which are supported by the molecular data. Thus, the species is endemic to Con Dao National Park in Ba Ria-Vung Tau Province, Vietnam. Furthermore, this study allows us revising the description of $A$. condaoense with, for the first time, supplemental key taxonomic characteristics and illustrating colourful photographs taken from the fresh materials. A key to all eight known Vietnamese species of sect. Fimbriata is also given.
\end{abstract}

Keywords: Araceae, Arisaema condaoense, chloroplast, Fimbriata, matK

\section{INTRODUCTION}

Arisaema condaoense was first described by Nguyen (2000) as a species belonging to Arisaema section Fimbriata based on dried specimens with only male inflorescences collected from Con Dao Island, Vung Tau-Ba Ria Province (N.T. Ban and Averyanov 385, HN!, 20 June 1989). Since then, no other collections of the species have been known.

Although its specific status was de facto accepted in Nguyen (2005), Nguyen, Vu (2009), Luu et al. $(2013 ; 2014)$ and Van et al., (2016), Gusman, Gusman (2006) stated in their revision of the genus that $A$. condaoense was very close to the polymorphic $A$. roxburghii Kunth which was widespread in the whole Indochina and Malay Peninsula and they questioned whether it was a form of the later or a different species. They suggested examining its fresh material for a correct identification. Until the present study, no efforts to delimit the species have been reported.

To ascertain its identity, we re-examined the questioned taxon. New fresh material of $A$. condaoense was collected in a field trip to the type location (Con Dao National Park) in June 2015 (Van Hong Thien H.T. Van 85, SGN!, approximate coordinates $8^{\circ} 42^{\prime} 47.34^{\prime \prime} \mathrm{N}, 106^{\circ} 37^{\prime} 2.52^{\prime \prime} \mathrm{E}$, at ca. $315 \mathrm{~m}$ above sea level). Our subsequent analyses of its molecular and morphological data proved it to be a good species that is re-described below. 


\section{MATERIALS AND METHODS}

\section{Materials}

DNA samples from nine taxa of Arisaema of three Arisaema sections (i.e. Anomala, Fimbriata and Sinarisaema) collected from southern regions of Vietnam (Table 1) were used in this study. All respective vouchered specimens were deposited at SGN (Southern Institute of Ecology).

Besides, mat $\mathrm{K}$ sequences of additional species from GenBank were also used in our phylogenetic analysis, including Arisaema erubescens (Wall.) Schott (GenBank: KT025779) - the type of the genus and Pinellia ternata (Thunb.) Makino (GenBank: JN090063).

Table 1. Accessions of nine taxa of Arisaema species sequenced in this study.

\begin{tabular}{lll}
\hline $\begin{array}{l}\text { Sequenced } \\
\text { voucher number }\end{array}$ & Taxon & Location of sampling \\
\hline H.T.Van 85 & A. condaoense & Con Dao National Park, Ba Ria-Vung Tau Province \\
H.T.Van 81 & $\begin{array}{l}\text { A. chauvanminhii } \\
\text { A. consanguineum subsp. } \\
\text { consanguineum }\end{array}$ & Bu Gia Map National Park, Binh Phuoc Province \\
H.T.Van 125 & A. garrettii & Kon Ka Kinh National Park, Gia Lai Province \\
KKK 503 & A. honbaense & Hon Ba Nature Reserve, Khanh Hoa Province \\
H.T.Van 89 & A. langbiangense & Langbiang Mountain, Lam Dong Province \\
H.T.Van 06 & A. petiolulatum & Da Lat City, Lam Dong Province \\
H.T Luu 1121 & A. pierreanum & Ba Den Mountain, Tay Ninh Province \\
H.T.Van 93 & A. roxburghii & Nui Cam Mountain, An Giang Province \\
H.T.Van 79 &
\end{tabular}

\section{Methods}

Plant specimens (Table 1) were collected and processed following the Kew Botanic Garden protocol (Govaerts, Frodin, 2002). Their fresh materials were noted and photographed of morphological characteristics of vegetative and reproductive plant organs, which were later used for taxonomic comparison and species identification.

Total genomic DNA was extracted from fresh leaf tissues using a Genomic DNA Purification Mini Kit (ThermoScientific Inc, USA). The target matK chloroplast DNA region was amplified by polymerase chain reaction (PCR) using primers (Fazekas et al., 2012). PCR were performed in an Eppendorf Mastercycler Gradient using a reaction mixture in volume of $25 \mu \mathrm{l}: 12.5 \mu \mathrm{l}$ Go Taq green master mix (Promega, USA), $1.25 \mu 1$ of each forward and reverse primers $(10 \mu \mathrm{M}), 9.5 \mu \mathrm{HPLC}$ water and $0.5 \mu 1$ DNA template $(25 \mu \mathrm{g} / \mathrm{ml})$. PCR cycles consisted of an initial denaturation for $5 \mathrm{~min}$ at $95^{\circ} \mathrm{C}$; 35 cycles of denaturation $\left(1 \mathrm{~min}\right.$ at $\left.94^{\circ} \mathrm{C}\right)$, annealing $\left(1 \mathrm{~min}\right.$ at $\left.50^{\circ} \mathrm{C}\right)$ and extension $\left(1: 30 \mathrm{~min}\right.$ at $\left.72^{\circ} \mathrm{C}\right)$; and a final extension at $72^{\circ} \mathrm{C}$ for $10 \mathrm{~min}$. The PCR products were visualised on $1.5 \%$ agarose gel and sent for purification and direct sequencing at Nam
Khoa Biotek Company Ltd. (Vietnam) using ABI 3130 XL Sequencer.

For multiple alignments, the software ClustalW (Thompson et al., 1994) was used to recognise the homology between sequences. Phylogenetic analysis was carried out with PAUP* ver. 4.0 Beta (Swofford, 2002) using Neighbor Joining methods with Pinellia ternata (Table 1) as an outgroup, following Jung et al. (2004). The statistical support for phylogenetic trees was calculated using the bootstrap method (Felsenstein, 1985) with 1,000 replicates. Bootstrap values of $50 \%$ or higher were performed to obtain cluster supports. The pairwise genetic distance (Kimura, 1980) was calculated using MEGA6 (Tamura et al., 2013).

\section{RESULTS AND DISCUSSION}

\section{The phylogenetic results}

The length of the obtained mat $\mathrm{K}$ nucleotide sequences ranged from 690 to $793 \mathrm{bp}$. The entire aligned length of matK region was $637 \mathrm{bp}$. In sect. Fimbriata, the matK alignment contained 637 positions of which 11 were variable. Accordingly, 
Arisaema roxburghii shared 5 mutations with $A$. condaoense, 4 mutations with $A$. chauvanminhii and 3 mutations with $A$. honbaense (Table 2). Nucleotides of $A$. condaoense differ absolutely from the other species at positions of 232, 351 and 540 . The pairwise genetic distances between $A$. roxburghii and $A$. condaoense, A. chauvanminhii, $A$. pierreanum and $A$. honbaense were 0.008, 0.003, 0.005 and 0.005 , respectively (Table 3 ).

As a result, the phylogenetic tree (Figure 1) shows that Arisaema species in southern Vietnam are clearly divided into three sections: Anomala, Fimbriata and Sinarisaema with bootstrap values of $100 \%, 92 \%$ and $97 \%$, respectively. This arrangement is consistent with the results of sectioning based on the morphological characteristics described by Gusman, Gusman (2006) as well as the molecular marker-based phylogenetic tree developed by OhiToma et al., (2016). In sect. Fimbriata, A. condaoense is outmost compared to the other species which have been known as distinct species in previous studies (Pham-Hoang, 2000; Luu et al., 2013, 2014; Van et al., 2016). The number of mutations in the mat $\mathrm{K}$ region and the consequent pairwise genetic distance between $A$. roxburghii and $A$. condaoense are larger than those between $A$. roxburghii and each of the other three species in the section (Table 2 and 3). Thus, the result supported that $A$. condaoense is a good species obviously genetically different from $A$. roxburghii and the other Arisaema species.

Table 2. Variable nucleotide positions of the matK region in the five species of sect. Fimbriata.

\begin{tabular}{llllllllllll}
\hline & $\mathbf{1 7}$ & $\mathbf{1 8}$ & $\mathbf{1 9}$ & $\mathbf{1 1 5}$ & $\mathbf{2 0 2}$ & $\mathbf{2 3 2}$ & $\mathbf{3 5 1}$ & $\mathbf{3 6 1}$ & $\mathbf{5 3 4}$ & $\mathbf{5 4 0}$ & $\mathbf{7 6 3}$ \\
\hline A. condaoense & - & $\mathrm{C}$ & $\mathrm{T}$ & $\mathrm{T}$ & $\mathrm{G}$ & $\mathrm{A}$ & $\mathrm{G}$ & $\mathrm{G}$ & $\mathrm{T}$ & $\mathrm{T}$ & - \\
A. pierreanum & $\mathrm{C}$ & $\mathrm{T}$ & $\mathrm{C}$ & $\mathrm{T}$ & $\mathrm{G}$ & $\mathrm{G}$ & $\mathrm{A}$ & $\mathrm{G}$ & $\mathrm{A}$ & $\mathrm{A}$ & - \\
A. roxburghii & - & $\mathrm{C}$ & $\mathrm{T}$ & $\mathrm{C}$ & $\mathrm{A}$ & $\mathrm{G}$ & $\mathrm{A}$ & $\mathrm{G}$ & $\mathrm{T}$ & $\mathrm{A}$ & - \\
A. chauvanminhii & $\mathrm{C}$ & $\mathrm{C}$ & $\mathrm{T}$ & $\mathrm{T}$ & $\mathrm{G}$ & $\mathrm{G}$ & $\mathrm{A}$ & $\mathrm{G}$ & $\mathrm{T}$ & $\mathrm{A}$ & $\mathrm{G}$ \\
A. honbaense & - & $\mathrm{C}$ & $\mathrm{T}$ & $\mathrm{T}$ & $\mathrm{G}$ & $\mathrm{G}$ & $\mathrm{A}$ & $\mathrm{A}$ & $\mathrm{T}$ & $\mathrm{A}$ & - \\
\hline
\end{tabular}

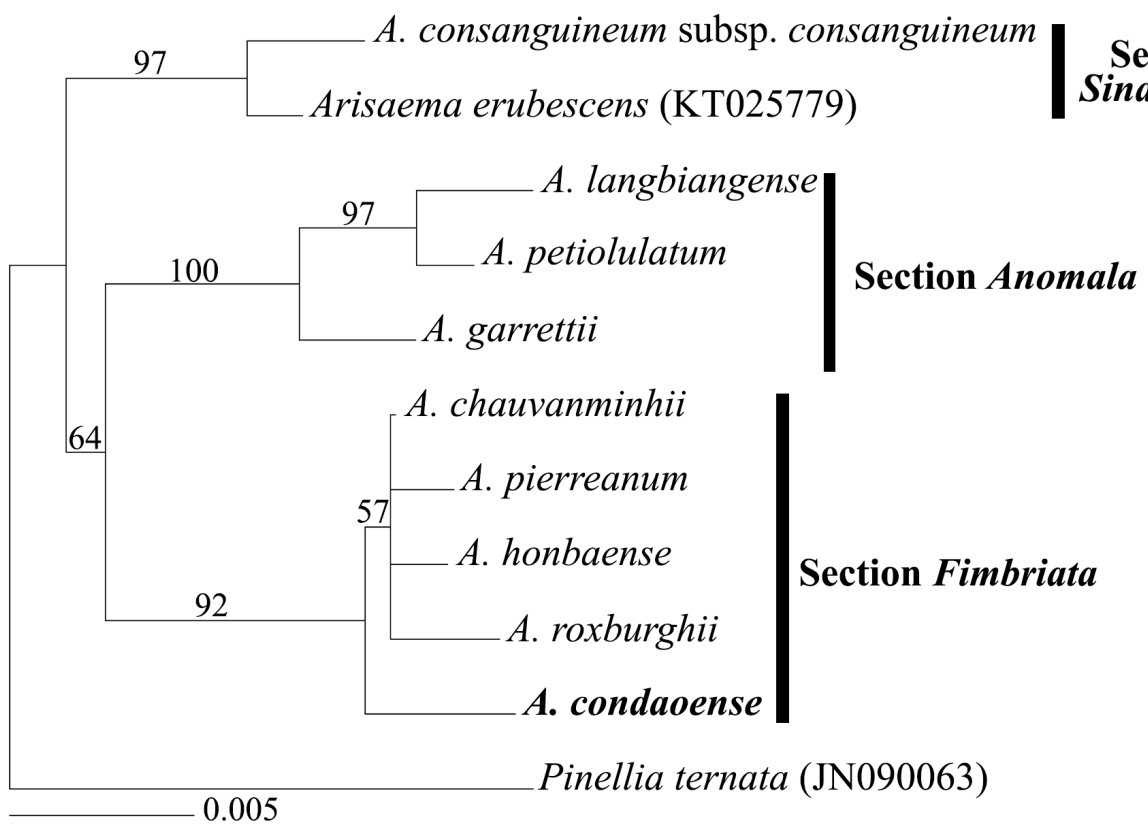

Figure 1. Phylogenetic tree of Arisaema species based on analysis of the matK nucleotide sequences. Topology was constriucted using the Neighbor Joining method with the bootstrap values of 1000 replicates. Walue of $50 \%$ or higher are shown above the nodes. 
Table 3. Mean pairwise genetic distances between Arisaema taxa based on the nucleotide sequences of the matK region.

\begin{tabular}{|c|c|c|c|c|c|c|c|c|c|c|c|}
\hline & 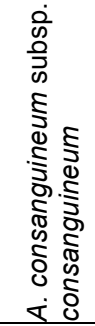 & 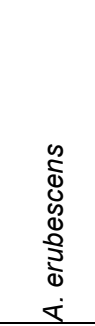 & 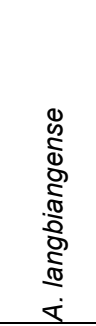 & 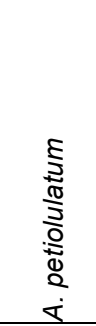 & 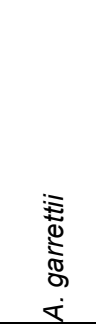 & 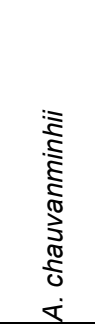 & 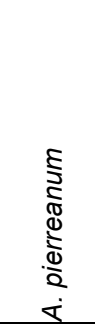 & $\begin{array}{l}\mathbb{D} \\
\mathscr{N} \\
\Phi \\
\mathbb{\Phi} \\
\mathbb{\delta} \\
\delta \\
\delta \\
\dot{\delta}\end{array}$ & 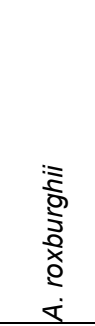 & $\begin{array}{l}0 \\
\infty \\
\Phi \\
\Phi \\
\delta \\
\delta \\
\delta \\
\delta \\
0 \\
\dot{0}\end{array}$ & 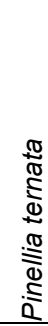 \\
\hline \multicolumn{12}{|l|}{$\begin{array}{l}\text { A. } \\
\text { consanguineum } \\
\text { subsp. } \\
\text { consanguineum }\end{array}$} \\
\hline A. erubescens & 0.005 & & & & & & & & & & \\
\hline A. langbiangense & 0.021 & 0.019 & & & & & & & & & \\
\hline A. petiolulatum & 0.019 & 0.018 & 0.005 & & & & & & & & \\
\hline A. garrettii & 0.018 & 0.016 & 0.010 & 0.008 & & & & & & & \\
\hline A. chauvanminhii & 0.018 & 0.016 & 0.019 & 0.018 & 0.016 & & & & & & \\
\hline A. pierreanum & 0.019 & 0.018 & 0.021 & 0.019 & 0.018 & 0.002 & & & & & \\
\hline A. honbaense & 0.019 & 0.016 & 0.021 & 0.019 & 0.018 & 0.002 & 0.003 & & & & \\
\hline A. roxburghii & 0.021 & 0.019 & 0.023 & 0.021 & 0.019 & 0.003 & 0.005 & 0.005 & & & \\
\hline A. condaoense & 0.019 & 0.018 & 0.024 & 0.023 & 0.021 & 0.005 & 0.006 & 0.006 & 0.008 & & \\
\hline Pinellia ternata & 0.024 & 0.023 & 0.030 & 0.028 & 0.026 & 0.026 & 0.028 & 0.028 & 0.026 & 0.028 & \\
\hline
\end{tabular}

\section{Taxonomic treatment}

Arisaema condaoense V.D. Nguyen, 2000. Aroideana, 23: 36, fig. 1; Govaert et al. 2002. World Checkl. Bibliogr. Arac. 190; Gusman and Gusman, 2002. Mon. Bot. Nat. Lov. 186; id. 2006. ed. second Rev. 209; V.D. Nguyen, 2005. in N.T. Ban Check1. P1. Vietn. 3: 880; V.D. Nguyen and T.C. Vu, 2009. Arac. Indoch. Agri. Pub. 3: 90. (Figure 2)

Herb deciduous, 30-40 cm high. Stem subterranean, sub-globose, ca. $4 \mathrm{~cm}$ in diameter and $1.5-2 \mathrm{~cm}$ high, with thick roots. Cataphylls 1-2, brown and up to $14 \mathrm{~cm}$ long. Leaves 1 or 2; petioles sheathing into pale green pseudostem at lower part, free above; pseudostem 12-26 cm long, $1-1.2 \mathrm{~cm}$ in diameter at base, pale green; free petiole $12-18 \mathrm{~cm}$ long, ca. $0.5 \mathrm{~cm}$ in diameter at base and ca. $0.3 \mathrm{~cm}$ in diameter at apex, pale green; leaf blade trifoliolate; leaflets 11-14 cm long, 7-9 cm wide, thin, glabrous, dark green above, pale green beneath, margins undulate, apex acuminate with up to $1.5-2 \mathrm{~cm}$, midrib adaxially impressed and abaxially prominent, lateral veins 16-20, collective vein at $0.2-0.5 \mathrm{~cm}$ from margin, central leaflet rhombic-elliptic, with base cuneate, petiolule ca. $0.5 \mathrm{~cm}$, lateral leaflets asymmetrical, with base obtuse, petiolule nearly absent. Inflorescence emerging from pseudostem; peduncle longer or shorter than petiole, $4.5-12 \mathrm{~cm}$ long, ca. $0.5 \mathrm{~cm}$ in diameter, pale green; spathe tube cylindrical, slender, $4.5-5 \mathrm{~cm}$, ca. $1 \mathrm{~cm}$ in diameter, slightly expanded at spathe mouth, white on both surfaces, yellowish near spathe limb; mouth-margins widely recurved, spathe limb curved over mouth, 5-6 cm long, 2.5-3 cm wide, ovate, light yellow on both surfaces, spathe tip acute, ending in a ca. $1.5 \mathrm{~cm}$ thread. Female spadix appendix $4.5-5 \mathrm{~cm}$, much exserted from spathe mouth, filiform, sinuous, 7.5-8 $\mathrm{cm}$ long, covered with ca. $3 \mathrm{~mm}$ long brown or green neuters just above the pistillate flowers, upper part naked, basally dark green, apically light yellow; female part ca. $2 \mathrm{~cm}$ long, cylindrical, pistils densely arranged; ovaries oval and green, 1-locular; ovules 45 , bottle-shaped, with basal placentation. Male spadix appendix $4.5-5 \mathrm{~cm}$ much exserted from spathe mouth, naked, filiform, sinuous, 6-6.5 cm long, basally dark green, apically light yellow; male part shortly stipitate, 
ca.0.4 cm long, synandrium of 3-4 stamens, loosely arranged, on $0.1 \mathrm{~cm}$ stipe; anthers shortly stipitate, thecae purple or cream with purple top and dehiscent by dark purple, elongated pore.
Type: N.T. Ban and Averyanov 385 (holo- and isotypes, HN!), Con Dao National Park, Ba Ria-Vung Tau Province, 20 June 1989; Van Hong Thien H.T. Van 85 (paratypes, SGN! \& PHH!, here designated).

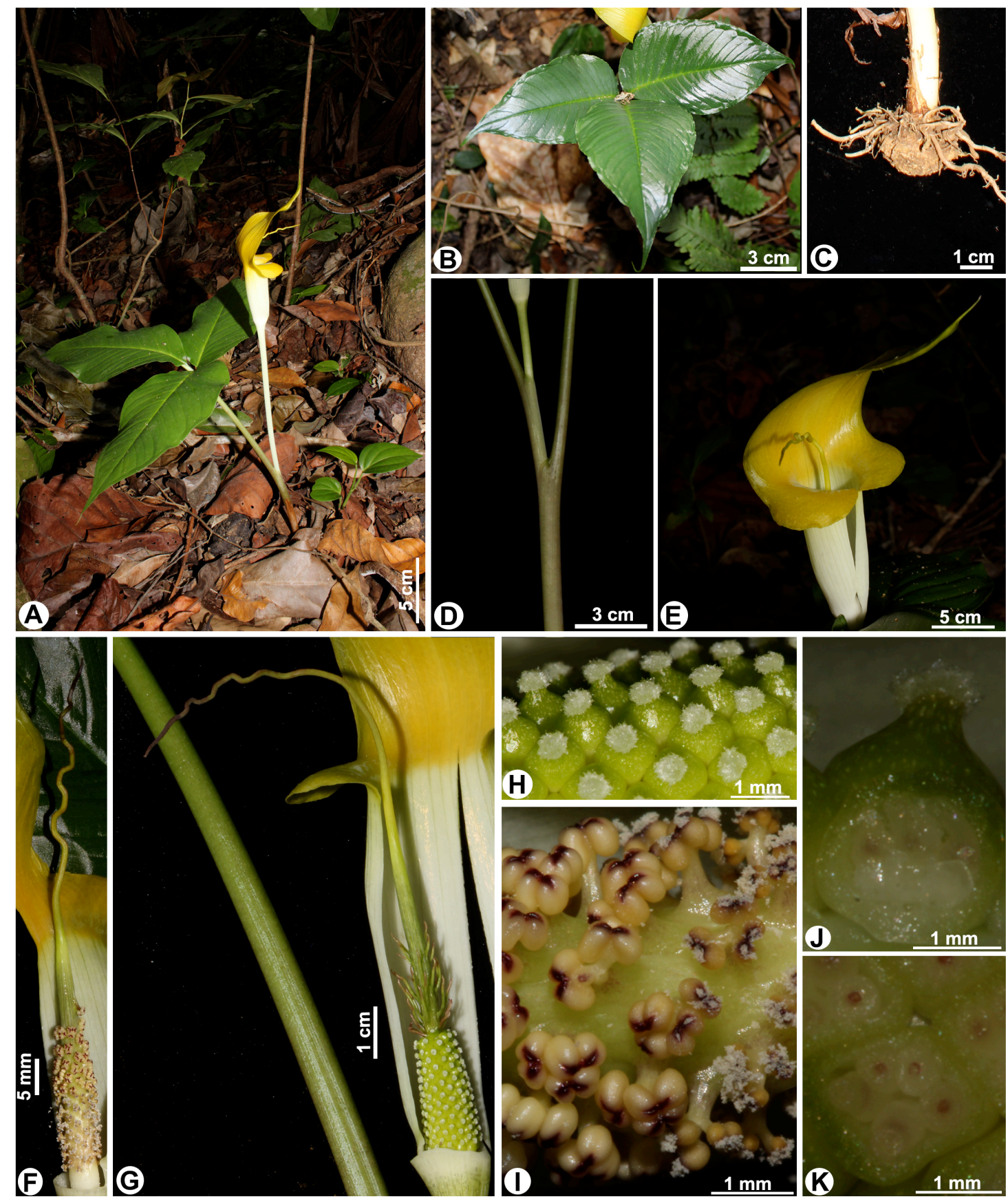

Figure 2. Arisaema condaoense, (A) The species in habitat, (B) Leaf blade, (C) Tuber, (D) Pseudostem, (E) Spathe, (F) Male spadix, (G) Female spadix, (H) Ovary and stigma, (I) Synandrium, (J) Longitudinal section of ovary, (K) Cross section of ovary. 
Habitat: Humus soils under tropical semievergreen forest. Flowering was seen in June to July.

Distribution: $A$. condaoense is only known from the type location.

Notes: A. condaoense obviously belongs to section Fimbriata and it is most closely relative to $A$. maxwellii, $A$. pierreanum and $A$. roxburghii in having: deciduous habit, sub-globose, tuberous, subterranean stem, rooting around the central shoot only, 1-2 bilaterally symmetrical leaves, trifoliolate leaf blade, yellow spathe, sessile, subulate and slender spadix appendage and sterile flowers (neuters) above the fertile region (at least in female spadices). However, it can be distinguished from $A$. pierreanum in having neuters on the female spadix appendix, thecae purple or cream with purple top and stamens grouped into stiped synandria ( $v s$. naked female spadix appendix, light yellow thecae and non-grouping stamens in $A$. pierreanum). It is different from $A$. maxwellii in having a tube shorter than spathe limb, naked male spadix appendage, neuters on the base of the female spadix appendix only and always widely recurved margins of the spathe tube ( $v s$. tube always much longer than spathe limb, bristle-like neuters on both male and female spadix appendices and hardly recurved margins of the spathe tube in $A$. maxwellii). Finally, $A$. condaoense differs from $A$. roxburghii in having yellow and not translucent spathe limb, spathe tube shorter than spathe limb and sinous spadix appendices ( $v s$. green or sometimes yellow and translucent spathe limb, tube longer than spathe limb and not sinous spadix appendices).

Based on the available literature (Nguyen, 2000; Pham-Hoang, 2000; Nguyen and Boyce, 2005; Gusman and Gusman, 2006; Nguyen, 2007; Luu et al., 2013 and 2014; Van et al., 2016) and the authors' field observations, the known Vietnamese species of Arisaema sect. Fimbriata can be distinguished by the following key:

1A. Spathe limb yellow

2A. Female spadix appendix without neuters A. pierreanum

2B. Female spadix appendix with neuters

3A. Spathe tube shorter than spathe limb; spadix appendices sinous

A. condaoense

3B. Spathe tube longer than spathe limb; spadix appendices not sinous

A. roxburghii
1B. Spathe limb green to deep brown

4A. Spathe limb deep brown A. averyanovii

4B. Spathe limb plain green or basically green with dark brown staining

5A. Spathe mouth margins reticulated in dark brown and widely recurved A. chauvanminhii

5B. Spathe mouth margins neither reticulated nor recurved

6A. Spathe limb with dark cross band at base

$$
\text { A. ramulosum }
$$

6B. Spathe limb without dark cross band at base

7A. Spadix appendix strongly apically fluted, backwards bent

A. honbaense

7B. Spadix appendix naked or with short neuters, not backwards bent

A. rostratum

\section{CONCLUSION}

Based on morphological and molecular data, $A$. condaoense is obviously distinct from its close species, including $A$. roxburghii, and therefore it should be accepted as a good species endemic to Con Dao National Park of Vietnam.

Acknowledgments: The authors thank the staffs of the Southern Institute of Ecology, Vietnam Academy of Science and Technology and Industrial University of Ho Chi Minh City for valuable supports. We are grateful to Con Dao National Park Management Board, especially Mr. Le Hong Son, Head of Science and International Cooperation, Mr. Nguyen Dinh Trung and forest rangers of Con Dao National Park for their permits and help in the field.

\section{REFERENCES}

Fazekas AJ, Kuzmina L, Newmaster SG, Hollingsworth PM (2012) DNA Barcoding methods for land plants. In: Kree WJ and Erickson DL (ed) DNA Barcodes: Method and Protocols. Meth Mol Biol 858: 223-252.

Felsenstein J (1985) Confidence limits on phylogenies: An approach using the bootstrap. Evolution 39: 783-791.

Govaerts R, Frodin D (2002) World checklist and bibliography of Araceae (and Acoraceae). Royal Botanic Gardens, Kew. 
Gusman G, Gusman L (2002) The genus Arisaema, A monograph for botanists and nature lovers. AR. Gantner Verlag, Ruggell, Lichtenstein.

Gusman G, Gusman L (2006) The genus Arisaema, A monograph for botanists and nature lovers. A.R.G. Gantner Verlag K.G.

Jung YH, Song EY, Chun SJ, Jang KC, Kim M, Kang SH, Kim SC (2004) Phylogenetic analysis of plastid $\operatorname{trnL}-t r n F$ sequences from Arisaema species (Araceae) in Korea. Euphytica 138: 81-88.

Kimura M (1980) A simple method for estimating evolutionary rates of base substitutions through comparative studies of nucleotide sequences. $J \mathrm{Mol}$ Evol 16: 11-120.

Luu HT, Tran G, Nguyen TT, Nguyen VD (2013) Arisaema honbaense (Araceae) - a new species from Vietnam. Folia malaysiana 14: 45-50.

Luu HT, Nguyen QD, Vu NL, Vuong DH, Kieu DT, Vo HS (2014) Arisaema chauvanminhii (Araceae), a new species from Vietnam. Ann Bot Fennici 51: 394-398.

Nguyen VD (2000) Two new species of Arisaema from Vietnam. Aroideana 23: 36-40.

Nguyen VD, in T.B Nguyen, Araceae Juss (2005) Vietnam checklist and bibliography of Araceae. Agriculture Publishing House, Hanoi, Vietnam 3: 871-898.

Nguyen VD, Boyce PC (2005) Two new species of genus Arisaema (Araceae) from northern Vietnam. Folia Malaysiana 6: 35-40.

Nguyen VD (2007) Two new species of the genus Arisaema Mart. (Araceae) described for Flora of Vietnam.
VNU Journal of Science, Natural Sciences and Technology 23: 86-90.

Nguyen VD, Vu TC (2009) New discoveries in the family Araceae in Indochina over the past twenty years. In: Proceedings of the third National Conference on Ecology and Biological Resources, 22 October 2009. Hanoi, Vietnam. Agriculture Publishing House, Hanoi, Vietnam, pp. 87-92.

Ohi-Toma T, Wu S, Murata H, Murata J (2016) An updated genus-wide phylogenetic analysis of Arisaema (Araceae) with reference to sections. Botanical Journal of the Linnean Society: 1-15.

Pham-Hoang H (2000) Araceae. In: Pham-Hoang, H. (Ed.) Cây cỏ Việt Nam: An illustrated flora of Vietnam, vol. 3. Youth Publishing House, Ho Chi Minh City, pp. 335-367 (in Vietnamese with English summary].

Swofford DL (2002) PAUP* Phylogenetic analysis using parsimony (*and other methods). Version 4.0 Beta. Sinauer Associates, Sunderland, Massachusetts.

Tamura K, Stecher G, Peterson D, Filipski A, Kumar S (2013) MEGA6: Molecular evolutionary genetics analysis version 6.0. Mol Biol Evol 30: 2725-2729.

Thompson DJ, Higgins DG, Gibson TJ (1994) CLUSTAL W: Improving the sensitivity of progressive multiple sequence alignment through sequence weighting, positionspecific gap penalties and weight matrix choice. Nucleic Acids Res 22: 4673-4680.

Van HT, Nguyen-Phi N, Luu HT (2016) On the taxonomic identity of Arisaema pierreanum Engl. (Araceae) in Vietnam. Science \& Technology Development Journal 19: 52-56.

\title{
XÁC ĐỊNH VỊ TRÍ PHÂN LOẠI LOÀI ARISAEMA CONDAOENSE (ARACEAE) DỤAA TRÊN DŨ LIẾU MỚI VỀ HÌNH THÁI VÀ PHÂN TỦ
}

\author{
Văn Hồng Thiện ${ }^{1}$, Nguyễn Phi Ngà ${ }^{2}$ Lưu Hồng Trường ${ }^{3,4}$ \\ ${ }^{1}$ Viện Công nghệ sinh học và Thực phẩm, Trưòng Đại học Công nghiệp Thành phố Hồ Chí Minh \\ ${ }^{2}$ Trưòng Đại học Khoa học tự nhiên, Đại hoc Quốc gia Thành phố Hồ Chí Minh \\ ${ }^{3} H o c$ viện Khoa hoc và Công nghệ, Viện Hàn lâm Khoa họ và Công nghệ Việt Nam \\ ${ }^{4}$ Viện Sinh thái học Miền Nam, Viện Hàn lâm Khoa hoc và Công nghệ Việt Nam
}

TÓM TẮT

Arisaema condaoense V.D. Nguyen được mô tả là một loài mới từ Vườn Quốc gia Côn Đảo thuộc tỉnh Bà Rịa-Vũng Tàu, Việt Nam, vào năm 2000. Tuy nhiên, một số nhà nghiên cứu về chi Arisaema đặt câu hỏi liệu đây có thực sự là một loài mới hay chỉ là một dạng của loài $A$. roxburghii Kunth vốn có phân bố rộng ở Đông Dương và bán đảo Malay; bởi vì $A$. condaoense được mô tả dựa trên các mẫu tiêu bản khô chỉ có phát hoa đực và thiếu một số đặc điểm quan trọng, nhất là ở phát hoa cái. Tháng 6 năm 2015, chúng tôi đã thu thập được cả phát hoa đực và cái của loài Arisaema sp. ở Vườn Quốc gia Côn Đảo. Từ đó, đoạn gen matK trên lục lạp của loài này đã được giải trình tự để phân tích, xây dựng cây phả hệ và so sánh với các loài Arisaema khác. Phân tích dữ liệu hình thái và phân tử đã chứng minh một cách chắc chắn rằng $A$. condaoense là một loài riêng biệt, 
không phải là đồng danh của $A$. roxburghii, đồng thời cũng hoàn toàn khác biệt với hai loài có hình thái tương tự là $A$. maxwellii và $A$. pierreanum. Cho nên, $A$. condaoense thực sự là một loài đặc hữu của Vườn Quốc gia Côn Đảo. Ngoài ra, kết quả nghiên cứu cũng giúp chúng tôi mô tả bổ sung loài $A$. condaoense với đầy đủ các đặc điểm phân loại và hình ảnh minh họa chi tiết lần đầu tiên thu thập được từ cây tươi, đồng thời xây dựng khóa định loại cho tất cả 8 loài thuộc section Fimbriata đã ghi nhận được tại Việt Nam.

Từ khóa: Araceae, Arisaema condaoense, chloroplast, Fimbriata, matK 